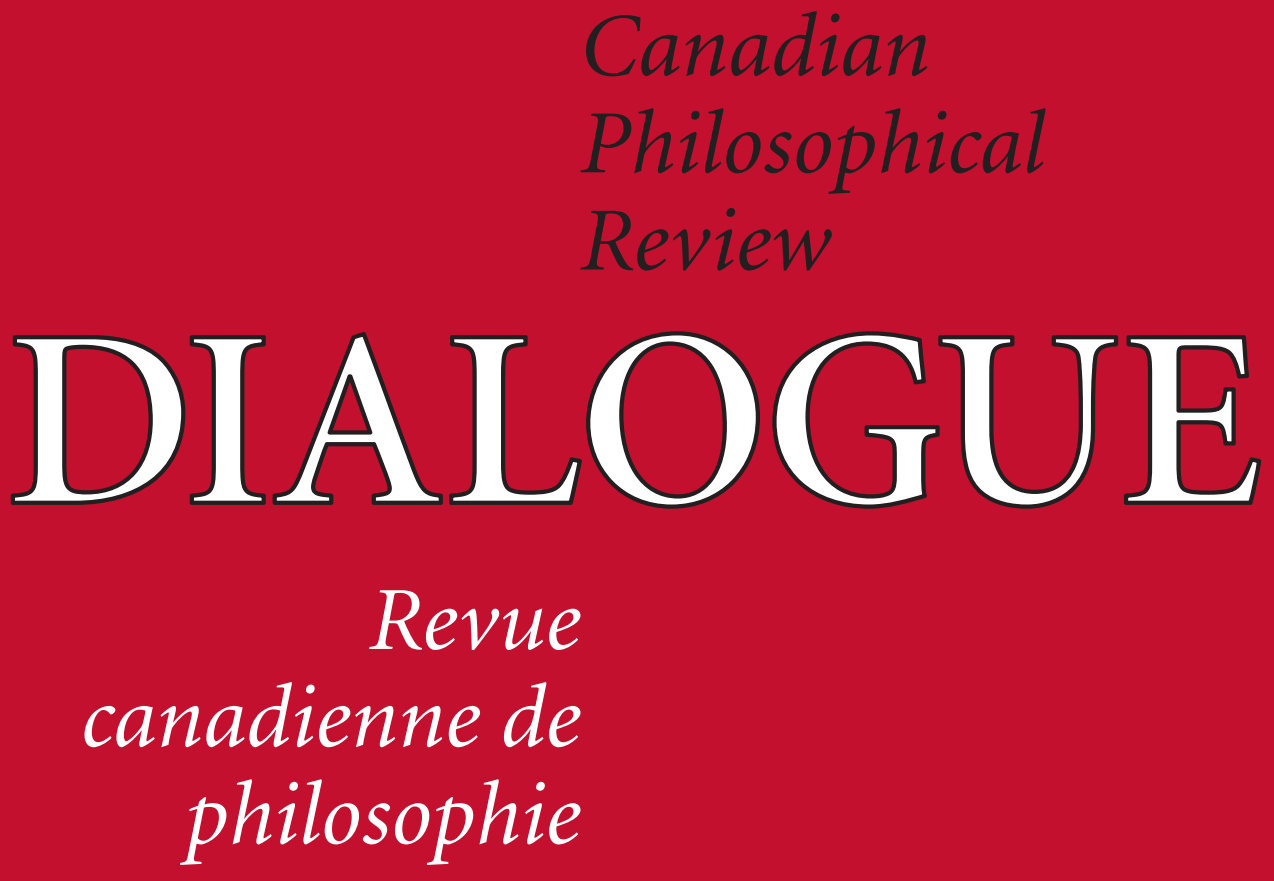




\begin{tabular}{lll}
\hline President / Président : & SANDRA LAPOINTE & McMaster University \\
Editors / Rédaction : & SUSAN DIMOCK & York University \\
& LUC LANGLOIS & Université Laval
\end{tabular}

\section{Editorial Board / Comité de rédaction}

\author{
ALAIN BEAULIEU \\ Université Laurentienne, Sudbury \\ JOCELYN BENOIST \\ Paris I Panthéon-Sorbonne \\ SAM BLACK \\ Simon Fraser University \\ CLAUDIA CARD \\ University of Wisconsin \\ BENOÎT CASTELNÉRAC \\ Université de Sherbrooke \\ SÉBASTIEN CHARLES \\ Université du Québec à Trois-Rivières \\ RYOA CHUNG \\ Université de Montréal \\ LORRAINE CODE \\ York University \\ CATHERINE COLLOBERT \\ Université d'Ottawa \\ RONALD DeSOUSA \\ University of Toronto \\ DANIEL DUMOUCHEL \\ Université de Montréal \\ LUC FAUCHER \\ Université du Québec à Montréal \\ ELISABETH GEDGE \\ McMaster University \\ NICHOLAS GRIFFIN \\ McMaster University \\ LAURENT JAFFRO \\ Paris I Panthéon-Sorbonne \\ WILL KYMLICKA \\ Queen's University
}

\author{
CLAUDE LAFLEUR \\ Université Laval \\ DOMINIQUE LEYDET \\ Université du Québec à Montréal \\ PETER LOPTSON \\ University of Guelph \\ DUNCAN MACINTOSH \\ Dalhousie University \\ JACK MACINTOSH \\ University of Calgary \\ JOCELYN MACLURE \\ Université Laval \\ MATHIEU MARION \\ Université du Québec à Montréal \\ CARL MATHESON \\ University of Manitoba \\ JEFF MITSCHERLING \\ University of Guelph \\ KATHLEEN OKRUHLIK \\ University of Western Ontario \\ JEFF PELLETIER \\ University of Alberta \\ PETER RAILTON \\ University of Michigan \\ WILLIAM SWEET \\ St. Francis Xavier University \\ CHRISTINE TAPPOLET \\ Université de Montréal \\ RICHARD VALLÉE \\ Université de Moncton, Campus \\ Shippagan
}

Editorial Policy: Dialogue publishes, in English and French, articles in all branches of philosophy and is open to contributions from any philosophical perspective. The articles and reviews in Dialogue are peer reviewed.

Politique éditoriale: Dialogue publie en anglais et en français des textes appartenant aux divers domaines de la philosophie, sans discrimination d'allégeance philosophique. Les articles et les études critiques soumis à Dialogue font l'objet d'une évaluation par les pairs.

Published quarterly in March, June, September, and December for the Canadian Philosophical Association with grant support from the Social Sciences and Humanities Research Council. The assistance and support of York University and the Université Laval are also gratefully acknowledged. / Revue trimestrielle de l'Association canadienne de philosophie publiée avec l'assistance financière du Conseil de recherches en sciences humaines. Dialogue bénéficie également du soutien de l'Université Laval et de l'Université York.

Information on the Canadian Philosophical Association can be found at www.acpcpa.ca. Pour plus d'information sur l'Association canadienne de philosophie, visitez le www.acpcpa.ca. 


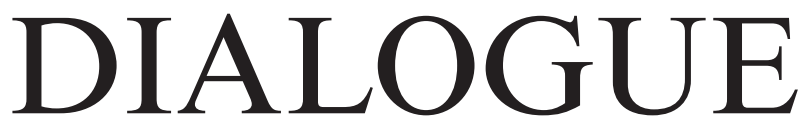

Canadian Philosophical Review / Revue canadienne de philosophie

Vol. 56, No. 1 March/Mars 2017

\section{Articles}

Métaphysique et éthique de la reproduction LYNDA GAUDEMARD 1

Moral Nativism: Some Controversies ROGER V.V. REX AND PAULO C. ABRANTES 21

Kane and Double on the Principle of Rational Explanation NEIL CAMPBELL 45

Is Charles Taylor (Still) a Weak Ontologist? MICHIEL MEIJER 65

What Goes Wrong in Habermas's Pragmatic Justification of (U)? JUVÉNAL NDAYAMBAJE 89

Narrative Constitution of Friendship CHRISTOPHER MOORE AND SAMUEL FREDERICK 111

Realism in Film: Less is More JIRI BENOVSKY 131

On the Arbitrariness Objection to the Threshold View MATTHEW LEE 143

Occam's Razor and Non-Voluntarist Accounts of Political Authority LUKE MARING 159

\section{Book Reviews/Comptes rendus}

JOSIANE BOULAD-AYOUB et al., dir., La vision nouvelle de la société dans l'Encyclopédie méthodique, Vols. I-III MARINA LEONI 175

WILLIAM JAWORSKI, Structure and the Metaphysics of Mind: How Hylomorphism Solves the Mind-Body Problem TRAVIS DUMSDAY 178

VINCENT ISRAEL-JOST, L'observation scientifique. Aspects philosophiques et pratiques

DAVID MONTMINY 180 


\section{ii Dialogue}

FREDERICK C. BEISER, Weltschmerz: Pessimism in German

Philosophy, 1860-1900

JOSEPH CAREW 184

PETER J. LEWIS, Quantum Ontology: A Guide to the Metaphysics

of Quantum Mechanics

JAMIE SHAW 185

YVON GAUTHIER, Towards an Arithmetical Logic: The Arithmetical

Foundations of Logic

ALAIN SÉGUY-DUCLOT 187

MaZVitTa ChIRIMuUta, Outside Color: Perceptual Science and the Puzzle of Color in Philosophy

JACLYN LANTHIER 190

ELHANAN YAKIRA, Spinoza and the Case for Philosophy THOMAS COLBOURNE 192

MAGALI ROQUES, L'essentialisme de Guillaume d'Ockham ROXANE NOËL 194

GILlian BRock AND MiCHAEl Blake, Debating Brain Drain:

May Governments Restrict Emigration?

GARY JAMES JASON 196

JAMES O. YOUNG, Critique of Pure Music

DAVID COLLINS 198

Books Received/Livres reçus 201 


\title{
Instructions to Contributors/Directives aux auteurs
}

Authors are invited to submit their manuscripts (including book reviews) for the Englishlanguage editor at the following URL: http://mc.manuscriptcentral.com/dia. Articles should be prepared for anonymous review (in RTF or Word format) and should include abstracts of 70-90 words in both English and French. Articles should also be accompanied by a separate title page with contact information and the author's university affiliation. Other correspondence should be sent electronically to: dialogue.english@acpcpa.ca. Books for review should be sent to:

\author{
Susan Dimock \\ York University \\ 4700 Keele St. \\ McLaughlin College, 237 \\ Toronto, ON M3J 1P3 \\ Canada
}

\section{Detailed instructions for contributors are available at https://www.acpcpa.ca/cpages/ dialogue-submissions}

Authors will receive PDF files containing their contributions to the journal, for their own use.

Dialogue has adopted the Cambridge University Press First View service, allowing manuscripts to be published — in complete and final format—online before they are allocated to a print issue, significantly reducing the time between acceptance and publication.

Les articles, notes et comptes rendus destinés à Dialogue doivent désormais être soumis en ligne. Les auteurs sont invités à soumettre une version électronique anonyme de leurs textes (formats .rtf ou .doc) à l'adresse URL suivante : http://mc.manuscriptcentral.com/dia. Ils sont priés de fournir, sur la première page de leur article, un résumé de 70 à 90 mots en anglais et en français. Le nom et l'affiliation institutionnelle de l'auteur doivent être fournis sur une page séparée. Pour toute information, veuillez vous adresser à l'adresse électronique suivante : dialogue.francais@acpcpa.ca.

Les livres pour compte rendu doivent être envoyés à l'adresse suivante :

\author{
Dialogue. Revue canadienne de philosophie \\ c/o Benoît Castelnérac \\ Département de philosophie et d'éthique appliquée \\ Université de Sherbrooke \\ 2500, boulevard de l'Université \\ Sherbrooke (Québec) J1K 2R1 \\ Canada
}

\section{Les auteurs trouveront des instructions détaillées à l'adresse web suivante : https://www. acpcpa.ca/cpages/dialogue-submissions}

Chaque auteur recevra pour son usage personnel une copie en format PDF de sa contribution à la revue.

Dialogue utilise le service First View de Cambridge University Press, qui permet de publier les articles en ligne, dans leur forme finale et complète, avant leur inclusion dans un numéro imprimé, réduisant de façon significative le délai entre l'acceptation des articles et leur 


\section{Call for Papers/Appel de textes}

\section{Call for Papers: Philosophy and its Borders}

Submissions are invited for a special issue of Dialogue: The Canadian Philosophical Review to be published in the second half of 2017. The topic of the issue is Philosophy and its Borders.

Philosophers have developed multiple connections with scholars in other disciplines, both in efforts to understand how different methods and models are employed in the search for knowledge, and to make available for philosophical reflection tools and insights discovered in other disciplines. Philosophy itself contains a number of different traditions, whose conflicts and tensions can be a rich source of creative possibility but can also be sites of exclusion or oppression. Recent challenges to the discipline have encouraged philosophers to recognize that Western philosophy itself-including analytic, continental, or pragmatist traditions - is just one among many possible approaches. Professional philosophers are increasingly asked to include non-Western philosophical sources in our curricula, for example, by bringing Eastern, Muslim, Indigenous, and Africana traditions into conversation with the Western canon. Feminists have long valued inter-disciplinary and multi-disciplinary work; they often draw on knowledge from different sources and standpoints in an effort to better understand and critique dominant modes of thought. In light of all this, it seems timely to address how best to work across borders in philosophy. Among the questions that might be explored are these:

* How do particular traditions and approaches exert power over others?

* What model or picture of the discipline ought we to present to our students as they are first learning "philosophy"?

* Pedagogy and the role of teaching philosophical traditions: what is appropriate when training students new to the discipline?

* What does it mean to draw disciplines and traditions together? 
* How have feminist philosophy, critical race theory, disability theory, and other critical approaches reshaped understandings of the discipline and its subdisciplines, such as bioethics, epistemology, ethics, metaphysics, and political philosophy?

* What successes have there been? What are the areas of conflict or tension?

* What does it mean to think of philosophy as having "core" areas? How do these relate to its borders?

* Non-Western and Indigenous philosophies have different understandings about what counts as philosophy. What challenges are posed by integrating them into disciplinary curricula?

* What does it mean to take the insights and norms of philosophical argumentation and bring them to bear in analyzing work in other disciplines?

* How can different philosophical methodologies be brought together? Do we take our methods with us when we cross borders? Do we weave different methods together?

* What becomes possible, ethically, politically, and scientifically, when we cross borders, especially given that disciplines understand the nature of "borders" in different ways?

Professor Jane Dryden at Mount Allison University will serve as the Guest Editor for this special issue. The issue will include articles originally presented at the 2016 CSWIP conference.

Contributors are invited to submit their papers directly to the ScholarOne manuscript management system that Dialogue uses: https://mc.manuscriptcentral. com/dia. In the "Type" portion of the submission process, please use "Special Issue: CSWIP" Please indicate that you want your paper considered for the Philosophy and its Borders special issue in your comments to the Editor. Submissions are open until 30 May 2017. Papers may be in English or French.

\section{Appel de textes : la philosophie et ses frontières}

Dialogue. Revue canadienne de philosophie reçoit les soumissions pour un numéro spécial à paraître au cours de la deuxième moitié de 2017, sous le thème : «La philosophie et ses frontières».

Les philosophes ont développé de multiples connexions avec d'autres disciplines, autant dans un effort pour comprendre les différentes méthodes et modèles employés dans la recherche du savoir que pour s'inspirer des outils et des idées découverts par celles-ci. La philosophie elle-même porte un certain nombre de traditions; les conflits et tensions qui existent entre elles peuvent être une riche source de possibilités créatrices, mais peuvent aussi donner lieu à l'exclusion ou à l'oppression. Des débats récents ont encouragé les philosophes à reconnaître 
que la philosophie occidentale elle-même, incluant les traditions analytique, continentale et pragmatique, devait accueillir à ses côtés les traditions orientales, autochtones et africaines. La philosophie féministe a, de son côté, souvent valorisé l'interdisciplinarité, rassemblant les connaissances de sources et de points de vue divers dans un effort pour mieux comprendre et critiquer les modèles de pensée dominants. Il paraît approprié, dans ces circonstances, de s'intéresser aux approches permettant de franchir ces frontières en philosophie. Voici des exemples de questions qui pourraient être explorées :

* Comment certaines traditions ou approches philosophiques exercentelles un pouvoir sur d'autres?

* Quel modèle ou quelle image de la discipline devons-nous présenter à nos étudiant-e-s lors de leur premier contact avec «la philosophie»?

* La pédagogie et le rôle de l'enseignement des traditions philosophiques : qu'est-ce qui est approprié lorsque nous introduisons des étudiant-e-s à la discipline?

* Que signifie «rapprocher des traditions et des disciplines»?

* Comment la philosophie féministe, la critical race theory, la disability theory et d'autres approches ont-elles transformé la compréhension de la discipline et de ses sous-disciplines comme la bioéthique, l'épistémologie, l'éthique, la métaphysique et la philosophie politique?

* Quels ont été les succès et où se situent les conflits et les tensions?

* Que signifie la tendance à présenter et penser la philosophie comme ayant des domaines «centraux»? Quel est alors le lien de ces «centres» avec les frontières de la discipline?

* Les philosophies non-occidentales et autochtones changent les attentes quant à ce qui doit être considéré comme de la philosophie. Quels défis sont posés par l'intégration de ces approches dans le curriculum philosophique?

* Comment peut-on transférer les idées et les normes de l'argumentation philosophique au cœur d'une analyse du travail d'autres disciplines?

* Comment les différentes méthodes philosophiques peuvent-elles être rassemblées? Nos méthodes nous suivent-elles lorsque nous traversons une frontière? Est-il possible de tisser entre elles différentes méthodes?

* Que rend possible cette traversée des frontières-éthiquement, politiquement et scientifiquement-, dans un contexte où les disciplines ont une compréhension différente de la nature de ces «frontières»?

Jane Dryden, professeur à Mount Allison University, agira comme rédactrice invitée pour ce numéro spécial. Le dossier inclura des articles présentés à l'origine dans le cadre de la conférence 2016 de la CSWIP (Canadian Society for Women in Philosophy). 
Les auteurs sont invités à soumettre leur article en ligne à l'adresse suivante : https://mc.manuscriptcentral.com/dia. Au moment de choisir le type de manuscrit soumis, veuillez sélectionner «Special Issue: CSWIP». Ajoutez un commentaire à la rédaction précisant que vous soumettez votre article pour le numéro spécial sur «La philosophie et ses frontières». La date limite de soumission est le 30 mai 2017. Les articles peuvent être rédigés en français ou en anglais. 